\title{
KREATIVITAS SENI BATIK DI DESA WISATA JARUM, KECAMATAN BAYAT, KLATEN JAWA TENGAH PADA MASA PANDEMI COVID-19
}

\author{
Sugeng Wardoyo ${ }^{1}$ \\ (Jurusan Kriya, Fakultas Seni Rupa, Institut Seni Indonesia Yogyakarta, sgngwardoyo@gmail.com ${ }^{1}$ ) \\ Tri Wulandari $^{2}$ \\ (Jurusan Kriya, Fakultas Seni Rupa, Institut Seni Indonesia Yogyakarta, triwulandari.kriya@gmail.com² ${ }^{2}$ )
}

\begin{abstract}
The batik group in Jarum village is a group that has had batik skills and play a role in maintaining the existence of Jarum village as a tourist village. But entering the era of the Covid-19 pandemic, the batik group in Jarum village experienced many complex problems related to creativity in the development of batik products and management of branding promotion governance in the Covid-19 pandemic. The urgency of the situation, then through the implementation of the P3WILSEN Program from ISI Yogyakarta is trying to offer alternative programs for developing batik designs and products, as well as the assistance of social media management. In the implementation of art counselling activities, this time using the method of literature studies, discussions, lectures, and experimental methods. The application of this method is intended so that the way obtained in the learning process gets optimal results. The result of the P3WILSEN program is creating a new creation batik motif Mojo Arum that has been registered in Intellectual Property Rights and making promotion branding Nunggak Semi. It is expected that in the future, there will be follow-up with the implementation of other mentoring programs that synergize and be sustainable.
\end{abstract}

Keywords: creativity, batik art, tourist villages, Covid-19 pandemic

Kelompok batik di Desa Jarum merupakan kelompok yang telah memiliki keterampilan membatik dan berperan dalam menjaga eksistensi Desa Jarum sebagai desa wisata. Namun memasuki era pandemi Covid-19, kelompok batik di Desa Jarum banyak mengalami permasalahan yang cukup kompleks, terkait dengan kreativitas dalam pengembangan produk batik dan manajemen tata kelola promosi branding di pandemi Covid-19. Adanya urgensi permasalah tersebut, maka melalui pelaksanaan Program P3wilsen dari ISI Yogyakarta ini mencoba menawarkan alternatif program pengembangan desain dan produk batik, serta pendampingan manajemen media sosial. Dalam pelaksanaan kegiatan penyuluhan seni kali ini digunakan metode kajian literatur, diskusi, ceramah, dan metode eksperimen. Penerapan metode ini dimaksudkan agar cara yang diperoleh dalam proses belajar mendapatkan hasil yang optimal. Hasil capaian Kegiatan P3wilsen, yaitu pembuatan motif batik kreasi baru Mojo Arum yang telah terdaftar dalam Hak Kekayaan Intelektual dan menciptakan branding promosi Nunggak Semi. Diharapkan ke depan terdapat tindak lanjut dengan pelaksanaan program pendampingan lainnya yang saling bersinergi dan berkesinambungan.

Kata Kunci: kreativitas, seni batik, desa wisata, pandemi Covid-19 


\section{PENDAHULUAN}

Sektor wisata telah menjadi salah satu pendapatan bagi daerah yang dinilai mampu mendatangkan devisa bagi daerah maupun negara. Pariwisata menjadi sektor yang menghasilkan multiplayer effect tidak hanya untuk daerah, namun juga bagi masyarakat setempat dalam perputaran roda perekonomian (Fanaqi et al., 2020). Desa wisata menyajikan sumber daya alam sekitar yang menjadi potensi untuk dikembangkan sebagai ikon sebuah desa wisata. Salah satunya adalah Desa Jarum yang telah ditetapkan sebagai desa wisata sejak tahun 2014.

Desa Jarum, Kebon, Banyuripan, dan Beluk merupakan desa yang memiliki kreasi batik dengan pewarna alami menggunakan tumbuhan dan tanaman yang ada di lingkungan sekitar seperti: pohon jati, mahoni, mangga, dan lainnya . Dari keempat desa tersebut, yang paling menonjol dan memiliki keunggulan pontesi wisata ialah Desa Jarum. Selain sebagai salah satu sentra batik warna alam, Desa Jarum juga memiliki potensi sebagai perajin perkakas rumah tangga, antara lain: memilki kerajinan batu cobek, kerajinan kayu batik, kerajinan tatah wayang, gerobak angkringan, tas kulit batik. Penghargaan sebagai desa wisata, Jarum juga mulai berbenah menyediakan berbagai sarana dan prasarana, guna mendukung program desa dengan menyediakan fasilitas homestay yang lengkap dengan pendukungnya.

Saat ini, batik masih tetap eksis digunakan dan mempunyai kebaruan baik dari aspek motif dan modelnya. Beberapa daerah menjadikan batik sebagai salah satu mata pencaharian yang dapat memberikan peningkatan pendapatan ekonomi (Maulida Larastati, 2021). Masyarakat Desa Jarum memiliki mata pencaharian sebagai perajin batik, kayu batik, pahat batu, yang biasanya mereka andalkan sebagai penghasilan utama dari sektor tersebut. Namun pada masa pandemi ini, penghasilan pokok yang didapatkan dari penjualan batik menurun drastis sejak memasuki masa pandemi Covid19 dalam rentang waktu 2019-2021.

Tahun 2020, Indonesia telah diprediksi bahwa prospek ekonomi mengalami penurunan dan memudar. Perlambatan ini sudah diprediksi sebelum pecahnya Covid-19. Covid-19 memberikan dampak pada perekonomian Indonesia yang semakin terpuruk. Tingkat angka kemiskinan diperkirakan menurun, akan tetapi proporsi orang yang rentan (tanpa jaminan ekonomi) akan meningkat pesat. Proyeksi pertumbuhan ekonomi tahun 2020 telah melemah secara signifikan pada 2,1 persen hingga minus 3,5 persen sebelum kembali ke rata-rata 5,4 persen pada tahun 2021-2022 ketika permintaan agregat telah pulih (Muhyiddin, 2020).

Pada masa pandemi Covid-19, sektor pariwisata dan ekonomi kreatif banyak mengalami permasalahan yang cukup kompleks pada umumnya, seperti: penurunan tingkat pengunjung yang datang di Desa Jarum, penurunan pendapatan ekonomi dari penjualan produk batik, serta pengurangan jumlah produksi produk batik. Selain itu, terdapat permasalahan khusus yang mereka hadapi saat ini seperti: 1) Kurangnya pengembangan inovasi desain motif batik yang mengusung potensi budaya lokal; 2) Kurangnya keterampilan dasar menggunakan teknologi informasi terkait dengan manajemen dan pemasaran yang dimiliki pelaku (SDM), serta terbatasnya pelatihan tentang pendampingan teknologi informasi yang diselenggarakan oleh pemerintah maupun pihak lain. Kesempatan untuk mengikuti kegiatan pelatihan-pelatihan menjadi belum maksimal, padahal mereka sangat membutuhkan tambahan pengetahuan pendokumentasian kegiatan kesenian mereka selama ini; serta 3) Masyarakat belum memiliki kelembagaan 
kesenian yang diperlukan untuk menjaga keberlanjutan kegiatan seni. Selama ini kegiatan mereka sering berhenti karena kurang adanya tata kelola yang baik di masyarakat.

Berdasarkan faktor urgensi permasalahan tersebut, program pembinaan dan pengembangan seni berdasarkan kewilayahan dipandang perlu untuk ditindaklanjuti. ISI Yogyakarta memiliki Program Pembinaan dan Pengembangan Wilayah Seni yang disebut dengan P3wilsen. Program ini diharapkan dapat menambah pengetahuan dan keterampilan bagi pelaku seni untuk penguatan dari sisi ekonomi, budaya, serta pariwisata.

Tujuan diadakannya pengembangan seni melalui P3wilsen ini adalah:

1. Meningkatkan pengetahuan, kemampuan, dan keterampilan baik secara pengetahuan berupa wawasan, pemahaman teknis dan pragmatis tentang sistem pemasaran berbasis online dan teknologi informasi;

2. Meningkatkan pengetahuan dan keterampilan dalam menginventarisasi dan pendokumentasian produk-produk yang sudah dibuat;

3. Mendorong para anggota agar memiliki kemampuan berkreasi dan motivasi dalam rangka pengembangan bidang keterampilan dan kewirausahaan.

Pendekatan pembinaan digunakan untuk mentransfer pengetahuan seni batik, fotografi, dan media sosial kepada peserta P3wilsen cukup beragam. Metode pembelajaran dalam kegiatan ini menggunakan metode kajian literatur, diskusi, ceramah, dan metode eksperimen. Penerapan metode ini dimaksudkan agar cara yang diperoleh dalam proses belajar mendapatkan hasil yang optimal.

\section{PEMBAHASAN}

Pengembangan desa wisata memiliki tujuan untuk meningkatkan pertumbuhan berbagai sektor ekonomi berbasis masyarakat, misalnya sektor kerajinan, jasa-perdagangan, dan lain sebagainya. Hal tersebut diharapkan mampu menjadi daya tarik bagi para wisatawan untuk mengunjungi suatu desa wisata (Tyas \& Damayanti, 2018).

Penguatan dan pengembangan desa wisata batik menjadi solusi yang tepat pada masa pandemi Covid-19 saat ini. Hal ini dikuatkan oleh beberapa objek kajian yang telah diteliti oleh peneliti sebelumnya dalam rentang waktu 2018-2021.

\begin{tabular}{|c|c|c|}
\hline $\begin{array}{c}\text { Tahu } \\
\mathrm{n}\end{array}$ & Peneliti & Judul \\
\hline 2021 & Maulida Larastati & $\begin{array}{l}\text { Pelestarian Budaya } \\
\text { Batik Nusantara } \\
\text { sebagai Identitas } \\
\text { Kultural melalui } \\
\text { Pameran di Museum } \\
\text { Batik Pekalongan } \\
\text { Pada Masa Covid-19 }\end{array}$ \\
\hline 2021 & $\begin{array}{l}\text { Risky Ayu Andriani, } \\
\text { Agung Wibowo, } \\
\text { Joko Winarno }\end{array}$ & $\begin{array}{l}\text { Pemberdayaan Desa } \\
\text { Wisata Samiran } \\
\text { Boyolali (Dewi Sambi) } \\
\text { Berdasarkan Teori } \\
\text { Analisis Talc (Tourism } \\
\text { Area Life Cycle) } \\
\end{array}$ \\
\hline 2020 & $\begin{array}{l}\text { Ika Fitriyani, } \\
\text { Nining Sudiyarti, } \\
\text { M. Nur Fietroh, }\end{array}$ & $\begin{array}{l}\text { Strategi Manajemen } \\
\text { Bisnis Pasca-Pandemi } \\
\text { Covid-19 }\end{array}$ \\
\hline 2020 & Muhyiddin & $\begin{array}{l}\text { Covid-19, New } \\
\text { Normal, dan } \\
\text { Perencanaan } \\
\text { Pembangunan di } \\
\text { Indonesia }\end{array}$ \\
\hline 2020 & Darmin Tuwu & $\begin{array}{l}\text { Kebijakan Pemerintah } \\
\text { dalam Penanganan } \\
\text { Pandemi Covid-19 }\end{array}$ \\
\hline 2020 & $\begin{array}{l}\text { Fanaqi, Chotijah } \\
\text { Pratiwi, Resty } \\
\text { Mustika } \\
\text { Firmansyah, } \\
\text { Firmansyah }\end{array}$ & $\begin{array}{l}\text { Strategi Branding } \\
\text { Pelaku Usaha } \\
\text { Pariwisata di Masa } \\
\text { Pandemi }\end{array}$ \\
\hline 2020 & $\begin{array}{l}\text { Nency Aprilia } \\
\text { Heydemans, Jiffry F. } \\
\text { Kawung, } \\
\text { Novel Omar Lanoh }\end{array}$ & $\begin{array}{l}\text { Perilaku Sosial di Era } \\
\text { Covid-19 }\end{array}$ \\
\hline 2018 & $\begin{array}{l}\text { Sahabudin Sidiq, } \\
\text { Tuasikal Muhammad } \\
\text { Amin, } \\
\text { Soni Laksono }\end{array}$ & $\begin{array}{l}\text { KKN-PPM } \\
\text { Pengembangan } \\
\text { Kerajinan Batik } \\
\text { sebagai Wisata } \\
\text { Edukasi di Desa } \\
\text { Kebon, Kecamatan } \\
\text { Bayat, Kabupaten } \\
\text { Klaten }\end{array}$ \\
\hline 2018 & $\begin{array}{l}\text { Ninik Wahyuning } \\
\text { Tyas, }\end{array}$ & $\begin{array}{l}\text { Potensi } \\
\text { Pengembangan Desa }\end{array}$ \\
\hline
\end{tabular}




\begin{tabular}{|l|l|l|}
\hline & Maya Damayanti & $\begin{array}{l}\text { Kliwonan sebagai } \\
\text { Desa Wisata Batik di } \\
\text { Kabupaten Sragen }\end{array}$ \\
\hline
\end{tabular}

Tabel 1. Kajian Literatur Hasil Penelitian

Kajian ini menelusuri literatur hasil penelitian sebelumnya yang berkaitan dengan kata kunci: seni batik, desa wisata, dan pandemi Covid-19, sehingga didapatkan 9 judul penelitian pada tabel 1 . Selanjutnya dilakukan analisis bibliometrik dengan menggunakan VosViewer.

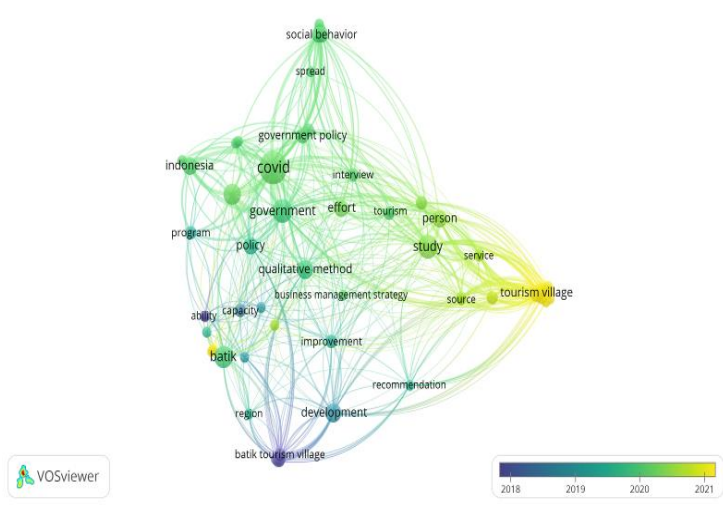

Gambar 1. Rentang Waktu Penelitian Terdahulu. (Sumber: VosViewer oleh Sugeng Wardoyo dan Tri Wulandari, 2021)

Gambar 1 menunjukkan batasan rentang waktu penelitian yang dilakukan oleh peneliti sebelumnya. Zona warna ungu menjelaskan bahwa penelitian dilaksanakan lebih dahulu dibandingkan dengan penelitian setelahnya yang berada di zona warna hijau dan disusul penelitian terbaru di zona warna kuning.

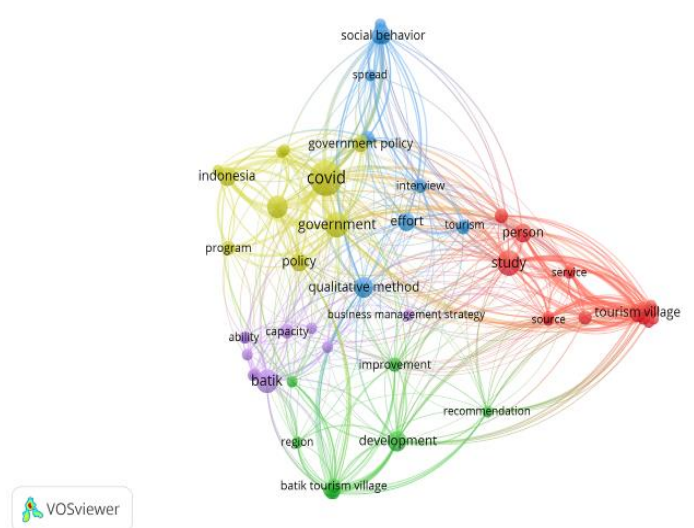

Gambar 2. Hubungan Antarobjek Kajian Penelitian (Sumber: VosViewer oleh Sugeng Wardoyo dan Tri Wulandari, 2021)
Gambar 2 menerangkan objek-objek kajian yang menjadi fokus penelitian oleh penelitian sebelumnya. Hasil analisis menunjukkan bahwa semakin besar lingkaran ikon objek menunjukkan bahwa objek kajian telah banyak diteliti dan dibahas secara luas. Berbeda dengan semakin kecil lingkaran ikon objek menunjukkan bahwa objek kajian belum banyak diteliti. Hal ini menjadi data dukung untuk menunjukkan letak perbedaan kajian ini dengan kajian sebelumnya. Kajian ini memiliki batasan objek pada desa wisata batik yang masih memiliki banyak peluang permasalahan untuk dikaji lebih mendalam.

Pengembangan desa wisata Jarum pada tahun 2021 diwujudkan dengan strategi peningkatan kreativitas seni batik pada masa pandemi Covid melalui salah satu program unggulan P3wilsen. Pelaksanaan kegiatan pada program P3wilsen di Desa Jarum ini meliputi pelatihan wawasan dan pengetahuan media sosial, teknologi informasi, wawasan dan pengetahuan proses pengembangan produk, desain, pewarnaan batik, kombinasi praktik pewujudannya, serta pengetahuan proses pendokumentasian dan pemasaran online.

Khalayak sasaran P3wilsen secara umum ialah masyarakat Desa Jarum Bayat, Klaten, Jawa Tengah, sekaligus secara khusus adalah pelaku ataupun kelompok seni batik "Sri Endah", "Batik Kayu Jino", "Batik Chamila", "Batik Nardho", "Batik Elsa", "Batik Rafael", yang masing-masing kelompok diwakili maksimal lima peserta.

Kegiatan P3wilsen dilaksanakan di dua tempat, yakni di rumah kelompok Batik "Sri Endah" dan di rumah kelompok "Jino Batik" Desa Jarum untuk pelatihan batik, fotografi produk, serta pelatihan penggunaan media sosial. Pembuatan profil desa dilakukan dengan mengeksplorasi Desa Jarum terhadap potensi-potensi yang ada baik bidang seni, pariwisata, sosial dan budaya Desa Jarum.

Pelaksanaan P3wilsen di Desa Jarum, 
Klaten, Jawa Tengah dimulai dari tanggal 28 September 2020 dan berakhir pada tanggal 21 November 2020. Adapun kegiatan program pelatihan P3wilsen ISI Yogyakarta di Desa Jarum, Kecamatan Bayat, Kabupaten Klaten adalah sebagai berikut ini:

1. Penyusunan rencana pembuatan jadwal kegiatan;

2. Eksplorasi potensi-potensi Desa Jarum, identifikasi karakter produk-produk dari 6 kelompok binaan, situs Mojo Arum, dan kekayaan lingkungan alam sekitar;

3. Pembuatan sketsa alternatif motif situs Mojo Arum;

4. Menentukankan sketsa terpilih dari motif Mojo Arum dan teknik yang digunakan untuk pewujudannya;

5. Proses pembuatan canting cap;

6. Pengetahuan dan praktik dasar fotografi produk, memaksimalkan penggunaan smartphone;

7. Sharing tentang media sosial, meliputi facebook, instagram, web site;

8. Proses pemolaan motif khas Mojo Arum;

9. Proses pelilinan motif khas Mojo Arum, meliputi: klowongan, cecekan dan tembokan;

10. Proses cap motif Mojo Arum;

11. Proses pewarnaan I menggunakan zat warna naptol dan indigosol;

12. Pembuatan sketsa bentuk kap lampu dinding dan kap lampu duduk, proses perwujudan;

13. Proses mbironi menutup warna pertama yang dikehendaki;

14. Proses pembuatan kap lampu berbahan paralon, kayu, kain dan mika;

15. Sharing dan memotivasi tentang pemasaran online;

16. Eksplorasi produk kerajinan batik kayu, pembuatan sketsa alternatif;

17. Pembuatan profil desa, dengan narasumber Kepala Desa Jarum dan para perajin;
18. Proses pewarnaan II menggunakan zat warna naptol, indigosol, dan kombinasi zat warna alam antara lain: jambal, tingi, tegeran dan jolawe;

19. Proses pelorodan kain, finishing kap lampu dinding, kap lampu duduk;

20. Pengenalan aplikasi dan cara mengedit foto produk menjadi lebih menarik;

21. Proses foto produk yang sudah dihasilkan;

22. Persiapan display produk dan pendaftaran HKI motif "Mojo Arum";

23. Membuat akun IG kelompok seni;

24. Pembuatan katalog, upload produk dan belajar menata feed Instagram.

\section{a. Kreativitas Penciptaan Motif Mojo Arum dan Kerajinan Produk Batik}

Motif batik dikembangkan untuk memenuhi kebutuhan konsumen yang berbeda, baik dari kalangan tua pada umumnya maupun kalangan generasi muda, remaja, dan dewasa. Pengembangaan corak motif batik membutuhkan adanyan kekuatan kreativitas yang tinggi dan menyesuaikan dengan faktor permintaan pasar maupun kondisi aktual saat ini (Sidiq et al., 2018).

Kelompok batik di Desa Jarum dalam kegiatan P3wilsen ini berhasil menciptakan motif kreasi baru dengan mengusung potensi budaya lokal. Andriani menjelaskan bahwa keragaman budaya dan wisata yang melimpah dapat ditelusuri melalui adanya potensi sebagai desa wisata. Desa wisata pada umumnya menyajikan keindahan suasana alam yang masih alami, keberadaan situs cagar budaya, maupun aktivitas keseharian masyarakat lokalnya (Andriani et al., 2021). Budaya lokal berkaitan erat dengan potensi peninggalan sejarah maupun situssitus sejarah yang ada di suatu daerah. Salah satu situs sejarah yang ada di desa Jarum, Kecamatan Bayat, yaitu: makam Sunan Tembayat di Desa Paseban dan situs Mojoarum di Desa Jarum. Kini Desa Jarum telah bertransformasi menjadi desa wisata, 
sehingga kondisi ini menuntut para perajin batik tetap berinovasi dan mengembangkan kreativitas walau dalam masa pandemi Covid19. Wujud kreativitas ditunjukkan dengan adanya ide penciptaan motif batik Mojo Arum. Motif ini memiliki kekhasan keindahan estetis dan makna filosofis, sehingga diharapkan motif ini dapat menjadi branding Desa Jarum sebagai desa wisata sekaligus wisata budaya.

Sewan Susanto menjelaskan bahwa teknik batik adalah suatu proses pengerjaan kain mulai dari persiapan mori batik hingga menjadi sebuah kain batik. Di dalam proses persiapan mencakup: nggirah atau ngetel nganji, dan ngemplong, sedangkan dalam proses membuat batik terdapat pekerjaan utama, seperti: pelekatan lilin, pewarnaan batik, dan penghilangan lilin (Susanto, 1980). Dalam pengembangan motif batik Mojo Arum ini menggunakan teknik batik tulis dan kombinasi teknik batik cap.

Teknik pewarnaan yang sering digunakan pada keseluruhan produk batik adalah teknik dye (celup), yang merupakan teknik mendasar dan paling konvensional di dalam memberikan warna pada kain (Wardoyo \& Widodo, 2016). Proses pewarnaan kain batik menggunakan teknik celup, sedangkan jenis warna batik yang digunakan yaitu warna alam dan warna sintetis. Hal ini bertujuan membekali pengembangan variasi hasil produk kain batik Desa Jarum.

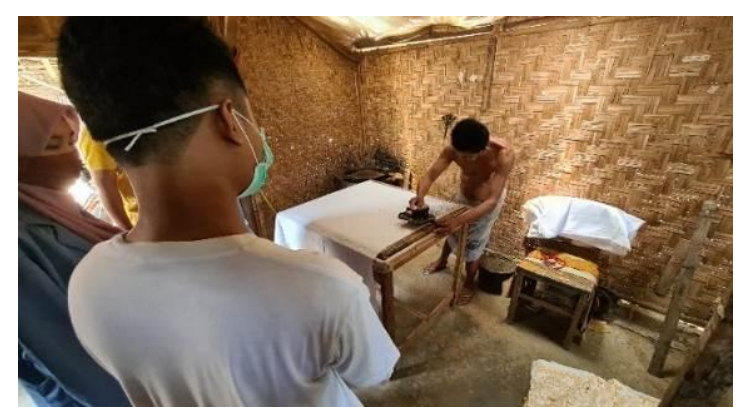

Gambar 3. Proses Mengecap Kain Mori (Sumber: Sugeng Wardoyo dan Tri Wulandari, 2020)

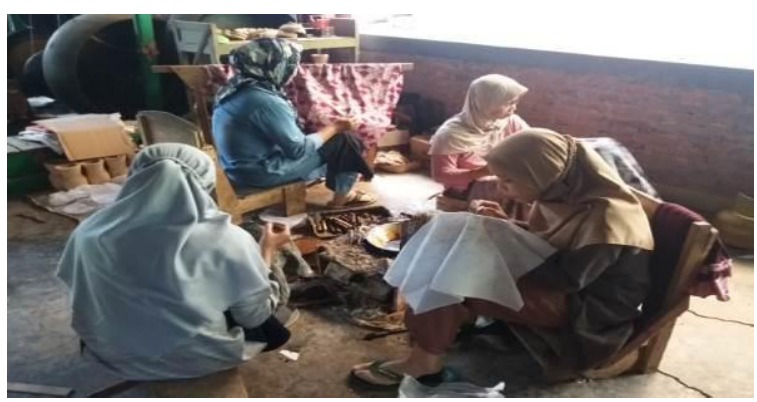

Gambar 4. Proses Membatik Kain Mori (Sumber: Sugeng Wardoyo dan Tri Wulandari, 2020)

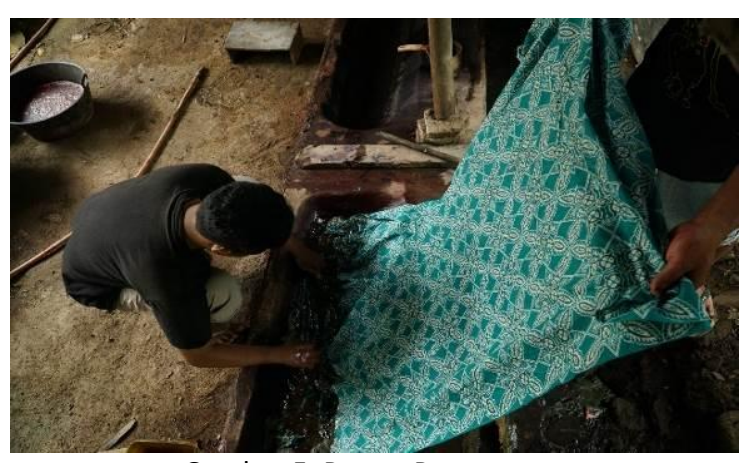

Gambar 5. Proses Pewarnaan

(Sumber: Sugeng Wardoyo dan Tri Wulandari, 2020)

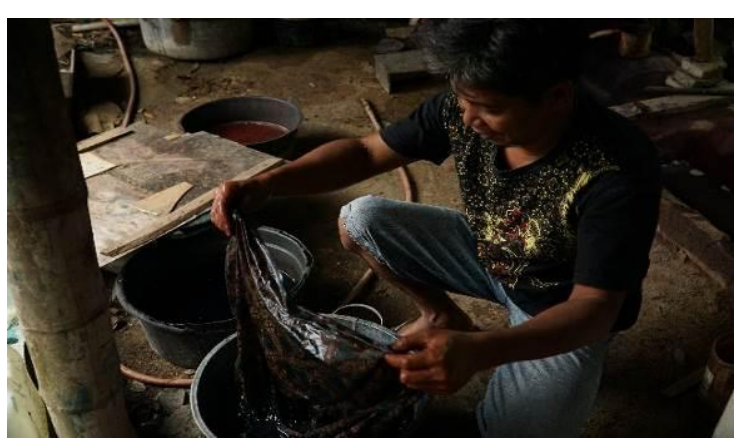

Gambar 6. Proses Pelorodan dan Pencucian.

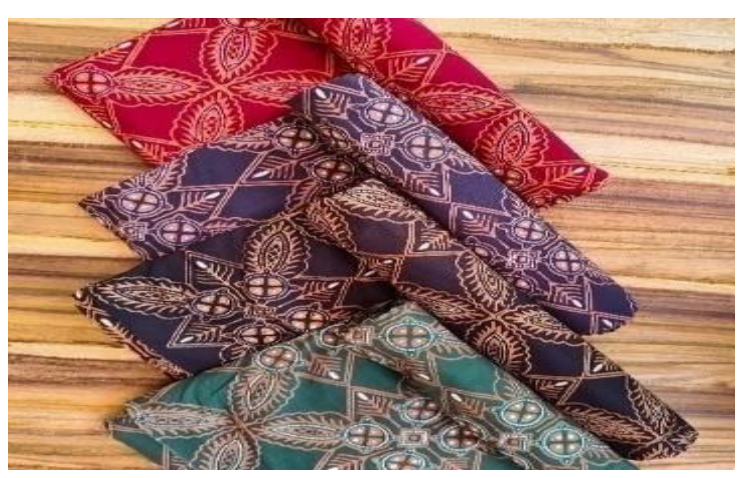

Gambar 7. Hasil Kain Batik

(Sumber: Sugeng Wardoyo dan Tri Wulandari, 2020)

Selain produk kain batik, kelompok seni batik "Sri Endah", "Batik Kayu Jino", "Batik Chamila", "Batik Nardho", "Batik Elsa", dan "Batik Rafael" juga menghasilkan produk 
masker yang menjadi tren gaya hidup dan kebutuhan utama di masa pandemi Covid-19. Masker batik merupakan produk yang paling banyak diminati dan memiliki daya jual potensial. Transformasi perubahan gaya hidup dan perilaku sosial yang sadar akan kebutuhan perlindungan diri dan menjaga kesehatan menjadi kesadaran setiap masyarakat. Produksi masker batik mempertimbangkan kebutuhan masyarakat membuat masker kain 2 atau 3 lapis sebagai bentuk antisipasi. Nency menjelaskan bahwa salah satu perilaku sosial masyarakat, yakni penggunaan masker merupakan solusi agar terhindar dari serangan virus dan mencegah penularan bagi orang lain. (Nency Aprilia Heydemans, Jiffry F. Kawung, 2020).

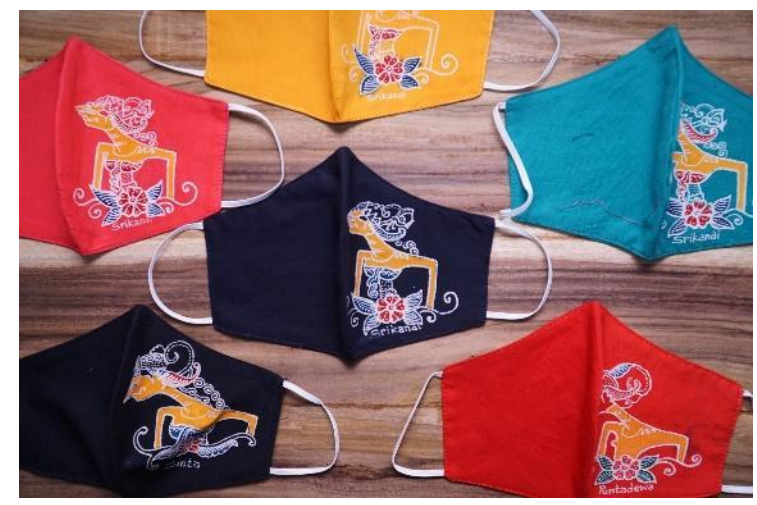

Gambar 8. Masker Batik

(Sumber: Sugeng Wardoyo dan Tri Wulandari, 2020)

Dalam proses pembuatan karya seni ataupun produk seni sering terjadi perubahanperubahan yang tidak diduga yang disebabkan dorongan faktor emosi (Wulandari, 2015). Dorongan faktor emosi dalam pembuatan produk seni kerajinan ditampilkan dalam spontanitas munculnya ide-ide kreatif. Produk kerajinan lainnya yang diproduksi dengan gagasan ide kreatif, seperti: kap lampu duduk, kap lampu dinding, dan dolanan anak, contoh sempritan burung dan pemukul bunyi. Produk ini dihasilkan dengan menggunakan teknik batik tulis di atas media kayu. Hal ini merupakan suatu aksi nyata merespon potensi alam sekitar Desa Jarum, yang banyak terdapat tumbuhan kayu-kayuan, seperti kayu sengon dan jati.

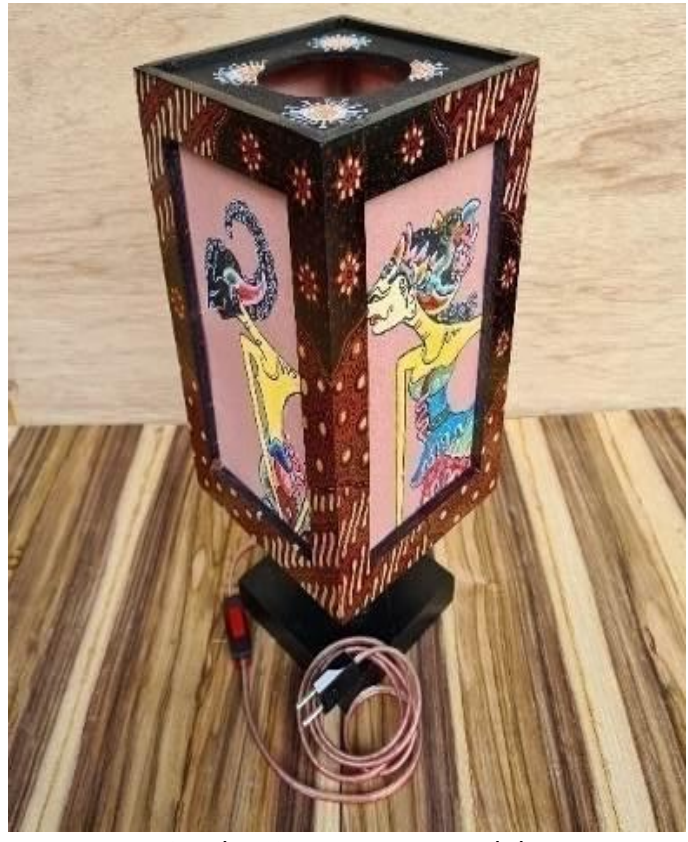

Gambar 9. Kap Lampu Duduk

(Sumber: Sugeng Wardoyo dan Tri Wulandari, 2020)

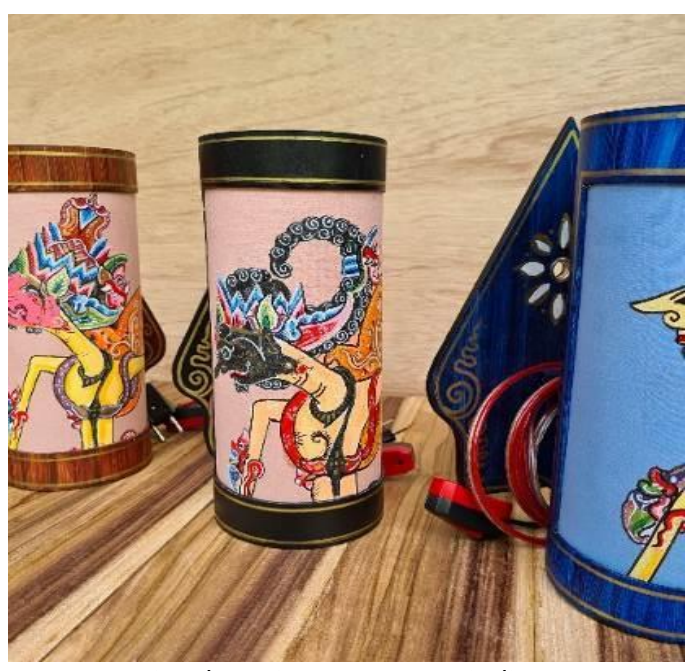

Gambar 10. Kap Lampu Dinding

(Sumber: Sugeng Wardoyo dan Tri Wulandari, 2020)

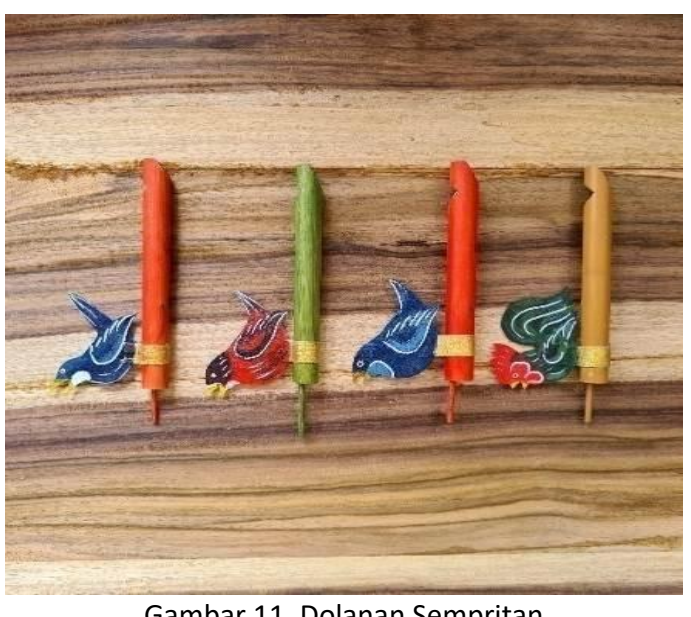

Gambar 11. Dolanan Sempritan

(Sumber: Sugeng Wardoyo dan Tri Wulandari, 2020) 


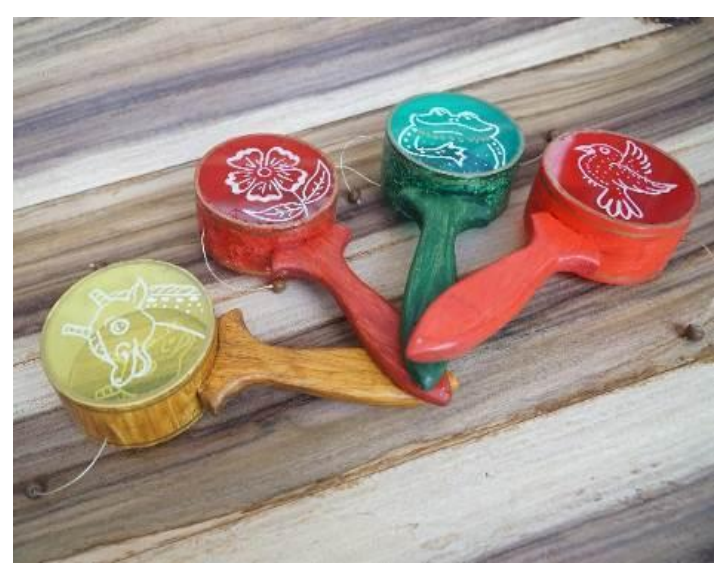

Gambar 12. Dolanan Pemukul Bunyi

(Sumber: Sugeng Wardoyo dan Tri Wulandari, 2020)

\section{b. Peran Promosi dan Branding di Tengah Pandemi Covid-19}

Masyarakat yang kreatif, inovatif dan dapat membaca peluang baru, maka dapat menciptakan sesuatu kebaruan yang menjadi tantangan di tengah pandemi Covid-19. Masyarakat kini telah beradaptasi dengan menciptakan aktivitas baru dengan cara menjual berbagai produk secara online.

Permasalahan utama dalam bidang manajemen sumber daya manusia pelaku UMKM di tengah pandemi Covid-19, yaitu minimnya pengetahuan, keterampilan, dan wawasan dalam memanfaatkan teknologi dan media sosial untuk peningkatan produktivitas bisnis. Wabah pandemi ini menuntut pelaku UMKM untuk dapat beradaptasi dengan kondisi saat ini. Salah satunya cara adaptasi yaitu dengan memanfaatkan teknologi yang ada sebagai media berjualan secara online, peningkatan kualitas pelayanan terhadap konsumen, serta membuat diversifikasi produk ataupun jasa untuk meningkatkan kinerja bisnisnya (Fitriyani et al., 2020).
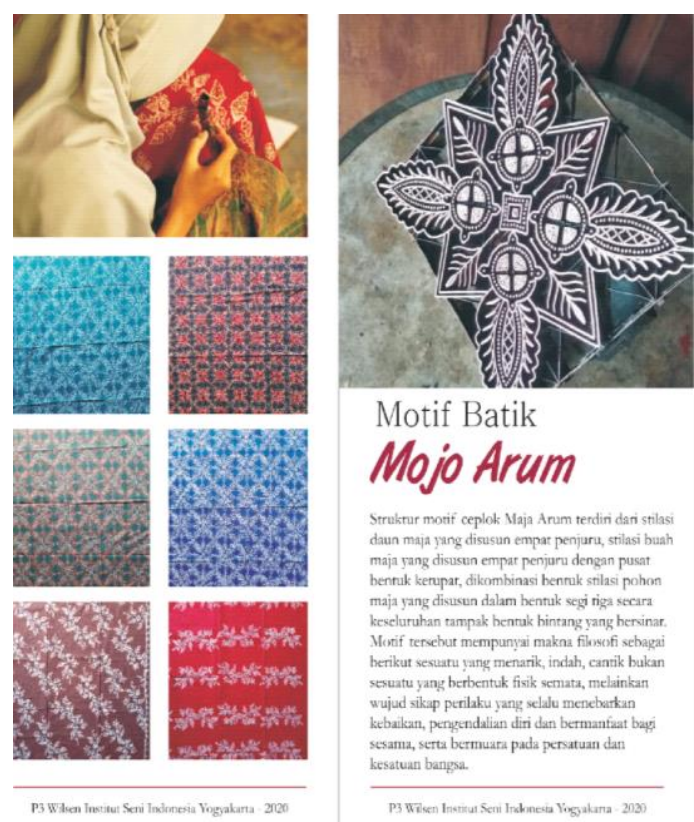

Motif Batik
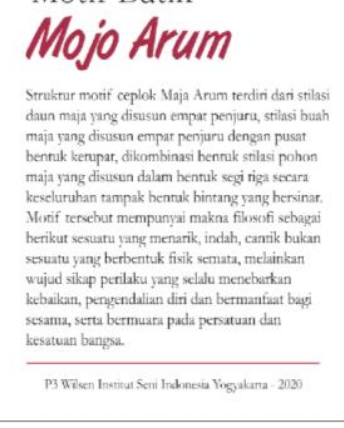

Gambar 13.Katalog Produk Online

(Sumber: Sugeng Wardoyo dan Tri Wulandari, 2020)

Karya yang dihasilkan dalam kegiatan P3wilsen ini memenuhi kriteria produk yang baik dari unsur artistik, estetis, maupun nilai ekonomis. Hasil produk batik antara lain: kain panjang atau jarik, kap lampu dinding, kap lampu duduk, dolanan anak, dan beberapa produk souvenir. Hasil produk tersebut didokumentasi untuk menjadi bahan media promosi di media sosial. P3wilsen ini juga melakukan pendampingan dalam pembuatan media sosial, seperti: akun Instagram, katalog kelompok seni "Nunggak Semi" sebagai brand baru. Tata cara mengelola dan memanajemen penjualan produk secara online dilaksanakan sebagai strategi penguatan promosi branding di tengah pandemi Covid-19. Secara keseluruhan kegiatan P3wilsen di Desa Jarum, Bayat, Klaten ini sesuai target harapan peserta binaan dan bermanfaat untuk masyarakat Desa Jarum. 


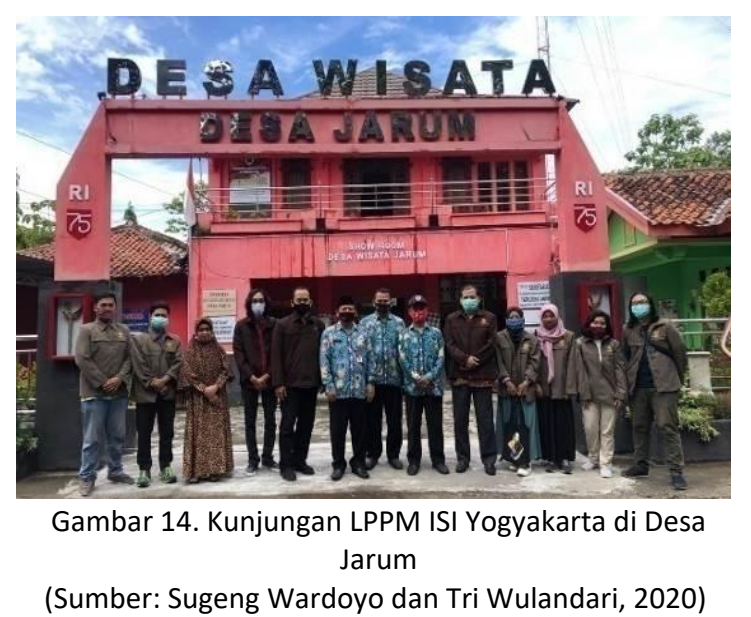

\section{PENUTUP}

Program ini dilaksanakan dengan konsep pelatihan keterampilan batik dan pendampingan tata kelola media sosial. Hal ini telah menjadi bukti nyata kebermanfaatan program pendampingan berdasarkan kewilayahan. P3WILSEN ISI Yogyakarta tahun 2020 di Desa Jarum, Bayat, Klaten merupakan bentuk kerja sama saling menguntungkan antara LPM ISI Yogyakarta dan masyarakat Desa Jarum.

Kegiatan ini dilaksanakan oleh pembina dan mahasiswa, program P3wilsen yang diharapkan dapat menjadi sarana implementasi transfer pengetahuan, keterampilan, dan berkolaborasi dengan masyarakat. Diharapkan ke depan terdapat tindak lanjut dengan pelaksanaan program pendampingan lainnya yang saling bersinergi dan berkesinambungan.

Hasil yang dicapai kegiatan P3wilsen dalam pembuatan motif batik kreasi baru Mojo Arum khusus untuk Desa Jarum dan telah tercatat HKI. Hal ini menjadi jawaban dan solusi dari permasalahan pengembangan inovasi desain motif batik yang mengusung potensi budaya lokal. Selanjutnya terkait permasalahan kurangnya keterampilan dasar menggunakan teknologi informasi terkait dengan manajemen dan pemasaran, telah teratasi dengan manajemen tata kelola media sosial sebagai sarana promosi dan branding
Nunggak Semi. Di dalam menyikapi masa pandemi ini bukan sebagai halangan, namun sebagai tantangan dan peluang baru untuk menciptakan produk baru dan beradaptasi dengan strategi yang tepat di era digital.

\section{DAFTAR PUSTAKA}

Andriani, R. A., Winarno, J., \& Wibowo, A. 2021. "Pemberdayaan Desa Wisata Samiran Boyolali (Dewi Sambi) Berdasarkan Teori Analisis Talc (Tourism Area Life Cycle)". AGRITEXTS: Journal of Agricultural Extension, 45(1), 59. https://doi.org/10.20961/agritexts.v45i1 .51540

Fanaqi, C., Pratiwi, R. M., \& Firmansyah, F. 2020. "Strategi Branding Pelaku Usaha Pariwisata di Masa Pandemi". Business Innovation and Entrepreneurship Journal, 2(4), 263-273.

https://doi.org/10.35899/biej.v2i4.172

Fitriyani, I., Sudiyarti, N., \& Fietroh, M. N. 2020. "Strategi Manajemen Bisnis Pasca Pandemi Covid-19". Indonesian Journal of Social Sciences and Humanities, 1(2), 87-95.

Maulida Larastati. 2021. Pelestarian Budaya Batik Nusantara sebagai Identitas Kultural melalui Pameran Di Museum Batik Pekalongan pada Masa Covid-19. 3(1), 46-50.

Muhyiddin. 2020. Covid-19. "New Normal, dan Perencanaan Pembangunan di Indonesia". The Indonesian Journal of Development Planning, 4(2), 240-252. https://doi.org/10.36574/jpp.v4i2.118

Nency Aprilia Heydemans, Jiffry F. Kawung, N. O. lanoh. (2020. "Perilaku Sosial di Era Covid-19". Journal of Chemical Information and Modeling, 53(9), 16891699.

Sidiq, S., Amin, T. M., \& Laksono, S. 2018. "KKN-PPM Pengembangan Kerajinan Batik Sebagai Wisata Edukasi Di Desa Kebon, Kecamatan Bayat, Kabupaten Klaten". Asian Journal of Innovation and 
..., 03(September), 336-341. Diambil dari https://journal.uii.ac.id/ajie/article/view $/ 11621$

Susanto, S. 1980. Seni Kerajinan Batik Indonesia. Yogyakarta: Balai Penelitian Batik dan Kerajinan, Lembaga Penelitian Pendidikan Industri, Departeman Perindustrian RI.

Tyas, N. W., \& Damayanti, M. 2018. "Potensi Pengembangan Desa Kliwonan sebagai Desa Wisata Batik di Kabupaten Sragen". Journal of Regional and Rural Development Planning, 2(1), 74. https://doi.org/10.29244/jp2wd.2018.2.
$1.74-89$

Wardoyo, S., \& Widodo, S. T. 2016." Inovasi Perancangan Motif Tie-Dye (Ikat Celup) Di Kota Yogyakarta". Corak, 5(1), 81-92. https://doi.org/10.24821/corak.v5i1.237 8

Wulandari, T. 2015." Konsep Tribuana/Triloka Pada Ornamen Relief Kalpataru di Kompleks Candi Prambanan sebagai Ide Penciptaan Karya Kriya Seni". Corak, 4(1), 63-71. https://doi.org/10.24821/corak.v4i1.236 1 